УДК 657.15:658.115]:005

Цятковська Олена, кандидат економічних наук, доцент, Київський національний економічний університет імені Вадима Гетьмана, кафедра податкового менеджменту та фінансового моніторингу, Київ, ORCID ID 0000-0001-8825-9778, tsiatkovska.elena@kneu.edu.ua

https://doi.org/10.29038/2786-4618-2021-04-38-47

\title{
БУХГАЛТЕРСЬКИЙ ОБЛІК В УПРАВЛІННІ ДЕРЖАВНИМИ УСТАНОВАМИ
}

У статті досліджено та проаналізовано економічну сутність та основні характеристики установ державного сектору відповідно до різних підходів, щодо формування структури державного сектору; визначено основних суб'єктів державного сектору, які узагальнено у два напрями відповідно до їх функціонального призначення; узагальнено основні характеристики для ідентифікації суб'єкта державного сектору $з$ урахуванням Класифікатора секторів економіки, системи національних рахунків, а також інших нормативно-правових документів; обгрунтовано необхідність поділу всіх суб'єктів державного сектору на державні підприємства та державні установи та наведено трактування економічної сутності «державна установа» та «державне підприємство»; встановлено взаємозв'язок та місце бухгалтерського обліку в управлінні державними установами, як суб'єктами державного сектору.

Ключові слова: бухгалтерський облік, державна установа, підприємство, державний сектор, суб’єкт.

Цятковская Елена, кандидат экономических наук, доцент, Киевский национальный экономический университет имени Вадима Гетьмана, кафедра налогового менеджмента и финансового мониторинга,

Киев

\section{БУХГАЛТЕРСКИЙ УЧЕТ В УПРАВЛЕНИИ ГОСУДАРСТВЕНЫМИ УЧРЕЖДЕНИЯМИ}

В статье исследована и проанализирована экономическая сущность и основные характеристики учреждений государственного сектора в соответствии с различными подходами к формированию структуры государственного сектора; определены основные субъекты государственного сектора, которые обобщены в два направления в соответствии с их функциональным назначением; обобщены основные характеристики для идентификации субъекта государственного сектора с учетом Классификатора секторов экономики, системы национальных счетов, а также других нормативно-правовых документов; обоснована необходимость разделения всех субъектов государственного сектора на государственные предприятия и государственные учреждения и приведена трактовка экономической сущности «государственное учреждение» и «государственное предприятие»; установлены взаимосвязь и место бухгалтерского учета в управлении государственными учреждениями как субъектами государственного сектора.

Ключевые слова: бухгалтерский учет, государственное учреждение, предприятие, государственный сектор, субъект.

Tsiatkovska Olena,

Degree: PhD in Economics, Position: Associate professor, Kyiv National Economic University named after Vadym Hetman, Department of Tax Management and Financial Monitoring, Kyiv 


\section{ACCOUNTING IN THE MANAGEMENT OF GOVERNMENT INSTITUTIONS}

Introduction. The country's entry to international organizations and close cooperation with various foreign partners is a key factor in modernizing and standardizing accounting in the public sector. Public sector institutions are one of the key actors influencing the efficiency and effectiveness of the economy as a whole. Public sector institutions are managed by heads of institutions on the basis of analysis, generalization and systematization of accounting data. That is why there is a link between the public institutions management and accounting.

The purpose of the article. The purpose of the article is to study the economic nature of the public sector as one of the economic sectors; to identify the main actors of the public sector through the separation of key identifiers; and to establish a link between the public institutions management and accounting.

Results. The article examines and analyzes the economic nature and main characteristics of public sector institutions under different approaches to the formation of the public sector structure; identifies the main subjects of the public sector, which are generalized in two directions according to their functional purpose; summarizes the main characteristics for the identification of the public sector entity, taking into account the Classifier of economic sectors, the system of national accounts, as well as other legal documents; justifies the necessity of division of all public sector subjects into "state enterprises" and "state institutions"; gives the interpretation of the economic nature of "state institution" and "state enterprise"; establishes the relationship and place of accounting in the management of public institutions as public sector entities.

Conclusions. The research established that accounting in public sector institutions is branched and dependent on the architecture of the public sector itself. This once again confirms that the economic activity of public sector institutions is reflected in various spheres of economic activity. Issues of accounting in public sector institutions are relevant today given all the transformation processes taking place in the economy.

Keywords: accounting, government agency, state enterprise, public sector, public entity.

Постановка проблеми та її значення. Економіка України за сучасних умов має розвиватися та відповідати європейським принципам та особливостям діяльності. Саме євроінтеграційні процеси $є$ головною причиною модернізації та вдосконалення системи державних фінансів 3 метою встановлення прозорості, зрозумілості та актуальності у показниках діяльності всіх суб'єктів господарювання.

Ефективність національної економіки залежить від всіх суб'єктів, але основу всіх змін та позитивних динамік розвитку звичайно є потужний державний сектор. Варто відзначити, що суб'єкти державного сектору є різними як за призначенням, так і за метою діяльності. Зокрема це можуть бути ринкові та неринкові виробники, фінансові та нефінансові установи. Але в той же час державна політика по відношенню до цих установ має бути єдиною. Для ведення прозорої діяльності установи державного сектору мають застосовувати єдині принципи діяльності, ведення бухгалтерського обліку та складання звітності. Щоб діяльність установ можна було проаналізувати, співставити та прийняти відповідні управлінські рішення. Успішне управління та ефективні результати діяльності суб’єктів господарювання можливе тільки при розумінні сутності, призначення та сфери діяльності цих суб'єктів. Саме тому вкрай важливо розуміти саму структуру діяльності установ державного сектору. При дослідженні державного сектору загалом, а управління установами державного сектору зокрема виникає питання щодо того, що входить до складу державного сектору та суб'єктів державного управління. I чи взагалі - це одне і те саме. Саме тому і потрібно детально дослідити структуру державного сектору економіки загалом, а також визначати значення бухгалтерського обліку в управлінні державними установами.

Аналіз останніх досліджень і публікацій. Питання економічної сутності та загалом бухгалтерського обліку в державному секторі досліджували різні науковці як вітчизняні, так i зарубіжні. Лук'янчикова Н., Майстер А., Макогон М., Мочерний С., Ходов Л. [4-7, 17], у своїх дослідженнях порушавали питання щодо державного сектору, як інституціональної одиниці економіки країни та визначали основні характеристики функціонування та співпраці 3 іншими суб'єктами господарювання. А от саме питання бухгалтерського обліку в державному секторі досліджували в своїх наукових працях Свірко С.В., Ловінська Л.Г., С.В., Єфименко, Т.I., Канцуров 
О.О., Дрозд І.К., Чечуліна О.О. [2-3]. Зокрема, Свірко С.В. у своїх дослідження порушувала питання щодо визначення в нормативних документах з бухгалтерського обліку для установ державного сектору та їх співставності з Класифікацією інституційних секторів економіки [15, С.42].

Але саме питання щодо структури державного сектору та основних суб'єктів щодо управління ними та взаємозв'язку з бухгалтерським обліком і надалі залишається невирішеним, як у нормативно-правових документах, так і в наукових дослідженнях.

Мета і завдання статті. Метою статті є дослідження економічної сутності державного сектору, як одного із секторів економіки, визначення основних суб'єктів державного сектору через виокремлення основних ідентифікаторів та встановлення взаємозв'язку в управлінні установами державного сектору з бухгалтерським обліком.

Викладення основного матеріалу та обгрунтування отриманих результатів дослідження. Визначення сутності, структури та основних елементів державного сектору економіки чітко визначено у Класифікації інституційних секторів економіки України. Відповідно до якої державний сектор економіки включає всі інституційні одиниці-резиденти, які: - контролюються одиницямирезидентами сектору загального державного управління; - віднесені до сектору загального державного управління; - віднесені до державних нефінансових корпорацій; - віднесені до державних фінансових корпорацій [9].

Установи державного сектору є досить різноплановими в чому і проявляється їх функціональна спрямованість та статусність у сучасному стані економіки загалом. Від ефективності управління установами державного сектору залежить загальні результати виконання бюджету країни. В історичному проміжку часу як сам підхід до поділу та функціонального призначення установ державного сектору, так і процес управління цими установами потребує детального опрацювання та дослідження.

Питання сутності державного сектору економіки часто було предметом дослідження. І особливо актуально це питання стало коли Україна почала рухатися напряму євроінтеграції. Відповідно всі нормативні документи та макроекономічні елементи економіки України загалом мають відповідати міжнародним підходам та міжнародній статистиці фінансів.

Макогон M.I. акцентує увагу на тому, що державний сектор утворює сектор державного управління, що включає органи влади різних рівнів, підвідомчі їм установи та державні інституційні одиниці, що входять в сектори нефінансових і фінансових корпорацій. А система державних фінансів включає сукупність державного та місцевих бюджетів, державні цільові фонди, фінанси підприємств і організацій державної та комунальної форм власності, державний кредит, державні фінансові інститути [6].

С. Мочерний, зазначає, що державний сектор - це частина економіки, що перебуває в державній власності, управляється, регулюється і контролюється державними органами [7].

Ходов Л.Г. вважає, що державний сектор - це «комплекс господарських об'єктів, що повністю або частково належать центральним та місцевим державним органам влади»[17, с.42].

Лук'янчикова Н.П. розглядає державний сектор як комплекс господарських об'єктів федерального чи місцевого підпорядкування, діяльність яких спрямована на реалізацію загальнодержавних економічних завдань $[4$, С.50].

Майстер А.В. надає власне визначення державного сектору економіки-сукупність суб'єктів господарювання, у яких переважає державна частка акціонерної власності та діяльність яких спрямована на виробництво визначених державою суспільно корисних товарів і надання соціально значущих суспільних послуг [5].

Сучасна національна економіка за своєю структурою класифікується за двома напрямами: секторальним і галузевим. У розвинених країнах секторальний поділ економіки здійснюється на основі використання міжнародних стандартів, зокрема "Керівництва по статистиці державних фінансів 2001 р." [15] та "Системи національних рахунків 2008 р." [16]. Відповідно до зазначених стандартів економіка країни в цілому поділяється на п'ять секторів - інституційних одиниць, що мають подібні цілі [6, С.25]. 
Отже, майже всі науковці дотримуються єдиних принципів щодо визначення сутності та структури державного сектору економіки. I в результаті аналізу наукових поглядів та Класифікації секторів економіки можна зробити висновок, що державний сектору - це сектор економіки, до складу якого входять державні фінансові та нефінансові корпорації, а також установи загального державного управління, які контролюються та здійснюють спільну політику 3 державними установами. Структура державного сектору відповідно до Класифікації секторів економіки подана на рисунку.1.

Управління державними фінансами напряму пов'язано із управлінням державними установами. Оскільки саме ефективне управління та організація функціонування установ державного сектору впливає та забезпечує результативність використання державних фінансів.

Варто відзначити, що управління державними установами здійснюється керівництвом установи, але 3 урахуванням тих повноважень, які покладено на керівників відповідно до установчих документів. Саме в установчих документах (положенні, статуті тощо) і визначається функціональне призначення тієї чи іншої установи. Оскільки державні установи не мають за мету отримати прибуток, то саме на них покладається завдання щодо забезпечення певного соціального ефекту для суспільства загалом, та кожного громадянина індивідуально. Кожна державна установа має індивідуальне призначення та особливості щодо діяльності. Але в сукупності всі установи забезпечують ефективну діяльність системи державного управління в країні.

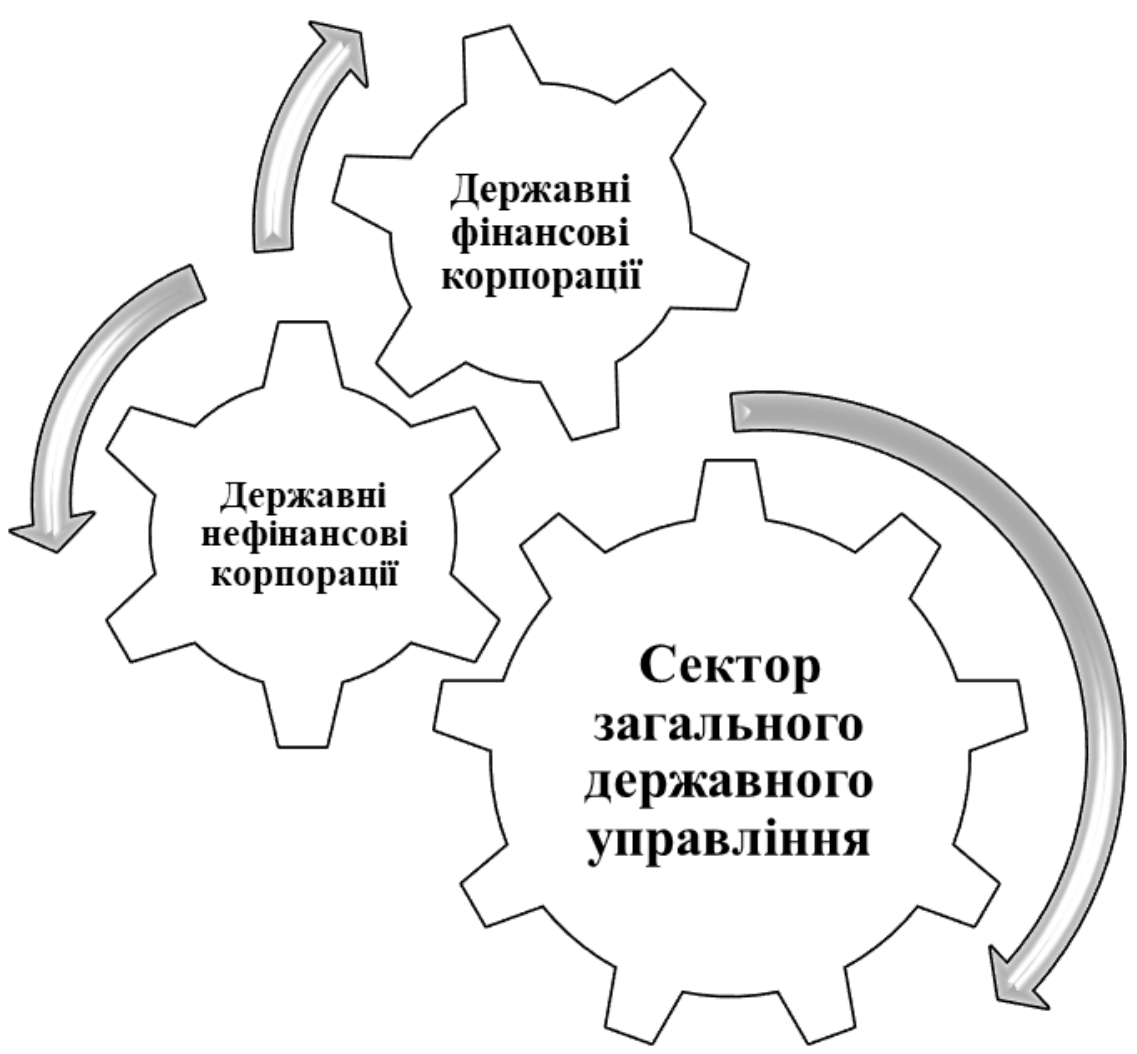

Рис.1. Структура функціонування державного сектору економіки

Джерело: сформовано автором на основі [9]

Ефективне функціонування державного сектору економіки $є$ важливою передумовою успішної міжнародної діяльності України та добробуту кожного громадянина України. Саме тому при здійсненні перших кроків у міжнародній сфері Україна мала забезпечити та надати своїм партнерам достовірну, співставну та прозору облікову інформацію. На основі якої міжнародні партнери мали 
здійснювати аналіз та оцінювати потенціал співпраці з державним сектором. Саме цим і викликано потужний та тривалий процес модернізації системи бухгалтерського обліку та фінансової звітності України.

3 початком модернізації бухгалтерського обліку та фінансової звітності в установах державного сектору, було сформовано та затверджено Стратегію модернізації системи бухгалтерського обліку в державному секторі на 2007-2015 роки [13]. Зокрема Стратегією встановлено, що вітчизняний бюджетний облік має відповідати міжнародним стандартам бухгалтерського обліку. Крім того варто відзначити, що саме із набуттям чинності цієї Стратегії і починає ототожнюватися бюджетний облік з бухгалтерським обліком в державному секторі. Хоча 3 цим ототожненням тяжко погодитися. Оскільки окрім бюджетних установ до структури державного сектору належать такі установи, як Національний банк України, державні підприємства, Пенсійний фонд України та інші державні фінансові та нефінансові корпорації.

Відповідно до проведеного аналізу структури державного сектору та іiі взаємозв’язку 3 бухгалтерським обліком, можна 3 впевненістю сказати, що державний сектор є багатовекторним. Зокрема цьому підтвердження є те, що установи державного сектору можна поділити на різні групи саме за веденням бухгалтерського обліку та його організацією. Тобто в структурі установ державного сектору застосовуються субрахунки бухгалтерського обліку чотирьох різних Планів рахунків. Державні нефінансові корпорації та державні фінансові корпорації, які можна класифікувати, як небанківських фінансові установи у своїй діяльності застосовують План рахунків бухгалтерського обліку активів, капіталу, зобов'язань і господарських операцій підприємств і організацій [10]. Але окрім небанківських фінансових установ до складу державних фінансових установ належать державні банківські установ, або як їх визначено Класифікаторі секторів економіки - Державні корпорації, що приймають депозити та Національний банк. I відповідно банківські установи використовують при веденні бухгалтерського обліку План рахунків бухгалтерського обліку банків України [11]. А зовсім відрізняється від плану рахунків призначеного для державних підприємств. Але окрім цього Плану рахунків окрема установа така, як Національний банк України має власний План рахунків бухгалтерського обліку. А суб'єкти сектору загального державного управління, де головним суб'єктом є Міністерство фінансів, яке здійснює та забезпечує ведення бухгалтерського обліку в бюджетних установах, свою господарську діяльність відображають на субрахунках бухгалтерського обліку визначених Планом рахунків бухгалтерського обліку для державного сектору [12].

Потрібно не забувати про багаторічні напрацювання вітчизняних науковців з бухгалтерського обліку, які в своїх дослідженнях облік в установах державного сектору ідентифікували, як облік в бюджетних установах або бюджетний облік. Але враховуючи сучасні виклики та реалії потрібно навести та проаналізувати визначення поняття бюджетна установа, яке наведено у Бюджетному кодексі України. А саме в ст.22 БКУ визначено, що бюджетні установи - органи державної влади, органи місцевого самоврядування, а також організації, створені ними у встановленому порядку, що повністю утримуються за рахунок відповідно державного бюджету чи місцевого бюджету [1]. Отже, проаналізувавши дане визначення можна говорити з впевненістю, що установи сектору загального державного управління не можна однозначно назвати, як бюджетні установи. Оскільки до складу цих установ належать також державні цільові фонди та Державна Казначейська служба України, які відповідно до ст.22 БКУ не віднесено до складу бюджетних установ. Саме тому перелік установ сектору загального державного управління має значно ширший перелік та потребує уточнення для узагальнення назви сукупності установ. Основні характеристики та особливості ідентифікації суб'єкта державного сектору наведено за допомогою структурно-логічної схеми ідентифікації суб'єкта державного сектору, яка наведена на рис.2. Структуризовано основні характеристики та особливості ідентифікації суб'єкта державного сектору, які подано за допомогою структурнологічної схеми ідентифікації суб'єкта державного сектору. За допомогою якої можна ідентифікувати та визначити, чи суб'єкт господарювання належить до державного підприємства чи до державної установи. 
За результатами проведеного дослідження можна зробити припущення, що архітектоніка державного сектору заснована на двох основних складових. Основними складовими державного сектору, та тими суб'єктами на яких покладається основна діяльність $є$ саме установи сектору загального державного управління та державні фінансові та нефінансові корпорації. Сфера діяльності та напрями у них зовсім різні, прикладом $є$ навіть те що перші $є$ неприбутковими, а інші $є$ прибутковими. Але для узагальнення та визначення суб'єктів державного сектору для подальшої ідентифікації відповідно до особливостей діяльності та функціонального призначення доцільно їх розмежувати та визначити основні напрями діяльності. Тобто за результатами проведеного дослідження доцільним буде, констатувати, що основу архітектоніки державного сектору економіки становлять державні підприємства та державні установи. Але для розуміння сутності доречно визначити та навести авторську дефініцію цих понять.

Отже, державна установа - це суб'єкт державного сектору, який діє на основі державної чи комунальної форми власності, має право впливу та управління на підприємства через частку у статутному капіталі, і яке надає послуги та реалізує товари на неринкових умовах, а майном користується на правах оперативного управління. Державні установи мають право отримувати бюджетні асигнування 3 державного чи місцевого бюджету залежно від органу, який їх утворив та відповідно до функціонального призначення цієї установи. Відповідно на отримані асигнування державна установа має право брати зобов'язання та здійснювати витрати за рахунок бюджетних коштів.

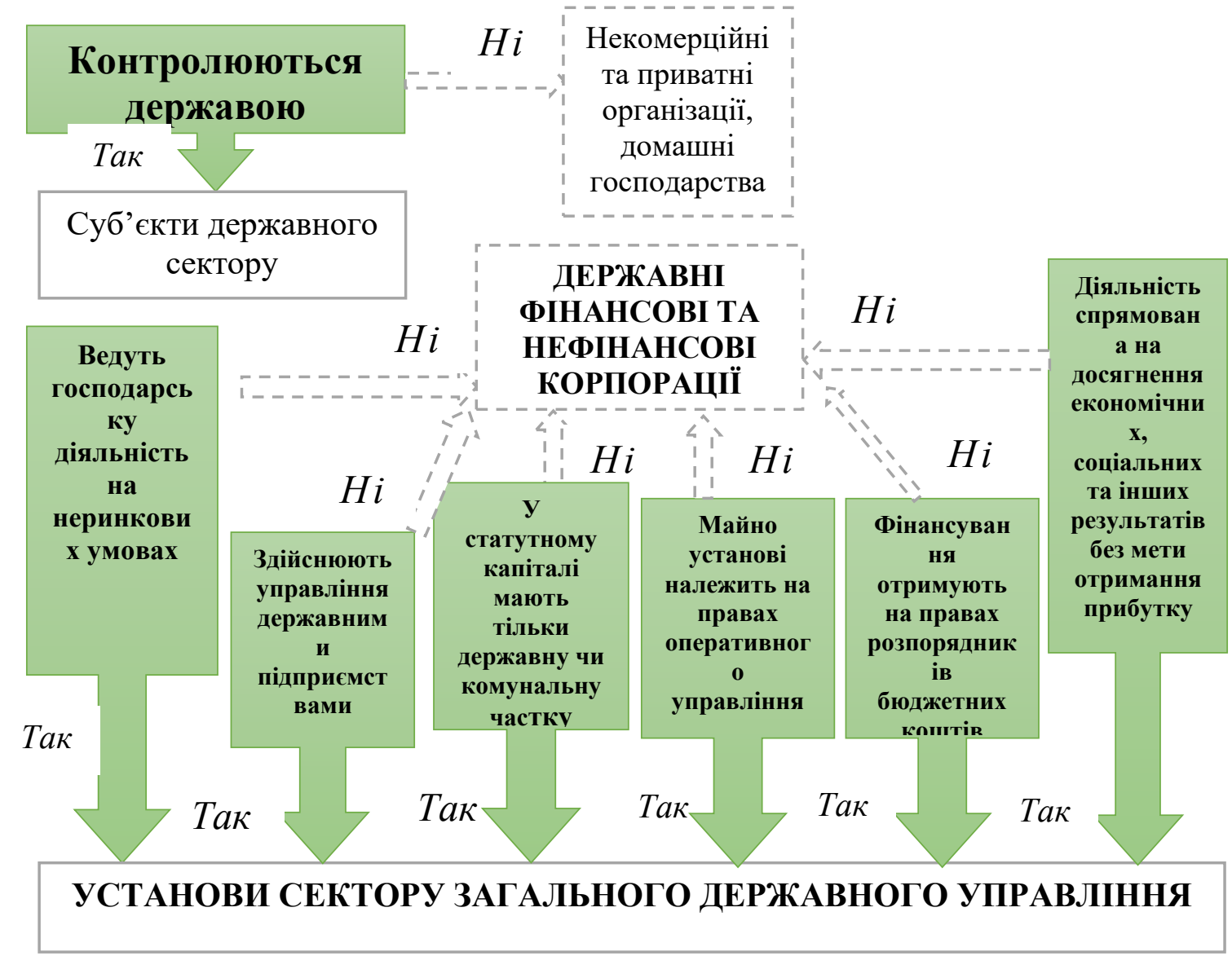

Рис.2 Структурно-логічна схема ідентифікаиії суб'єкта державного сектору

Джерело: сформовано автором

Державне підприємство - це суб'єкт державного сектору, який створений та контролюється державною установою для задоволення суспільних потреб, надають послуги та реалізує товар на 
ринкових умовах, а державним майно користується на правах господарського відання. На відмінну від державних установ ці підприємства не отримують бюджетні асигнування 3 державного чи місцевого бюджету. Але державні підприємства через державні установи можуть отримувати бюджетні кошти, як фінансову підтримку, або кошти на виконання певних цільових програм соціального, культурного, освітнього чи іншого напрямку.

Для державних установ основною сферою їх діяльності є законодавча, виконавча або судова влада, а також державні позабюджетні фонди та фонди соціального забезпечення. Всі ці установи мають пряме джерело доходу загального або спеціального фонду, відповідно шляхом отримання бюджетних асигнувань відповідно з державного чи місцевого бюджете, доходів або отримання доходів спеціального фонду.

Варто відзначити, що державні установи, як суб'єкти державного сектору є розпорядниками бюджетних коштів та є неприбутковими установами, а от державні підприємства можуть бути тільки одержувачами бюджетних коштів і як неприбутковими, так і прибутковими установами.

Підтвердженням того, що потрібно привести у відповідність у нормативних документах понятійний апарат та суб'єкти державного сектору, які є неприбутковими ідентифікувати, як державні установи, є основні положення «Системи національних рахунків». У системі національних рахунків окремий розділ приділено рахункам доходів і витрат на фінансування капітальних витрат:

1. Нефінансові корпоративні та схожі з ними підприємства.

2. Фінансові установи.

3. Державні установи.

4. Приватні некомерційні організації, що обслуговують домашні господарства.

5. Домашні господарства з урахуванням приватних нефінансових некорпоративних підприємств.

I як результат, статистична інформація про інституційні сектори економіки України буде відповідати міжнародним вимогам до статистичної інформації.

Отже, в результаті проведеного дослідження можна говорити, що бухгалтерський облік в установах державного сектору є розгалуженим і залежним від архітектоніки самого державного сектору. Це ще раз підтверджує, що господарська діяльність установ державного сектору відображена у різних сферах діяльності економіки.

Варто відзначити, що окрім того, що для різних суб'єктів державного сектору економіки прийнятним до використання є той чи інший План рахунків, так і стандарти бухгалтерського обліку теж різняться. Зокрема, державні нефінансові та фінансові установи дотримуються положень визначених НП(С)БО та МСБО, а от установи загального державного управління - НП(С)БОДС та МСБОДС.

Питання бухгалтерського обліку в установах державного сектору $є$ актуальними на сьогоднішній день враховуючи всі трансформаційні процеси, які відбуваються в економіці країни. А ще більш актуальним стало тоді, коли було розроблено та затверджено НП(С)БОДС та План рахунків бухгалтерського обліку для державного сектору. Оскільки саме в Національних положення (стандартах) бухгалтерського обліку для державного сектору було визначено, що вони для суб'єктів державного сектору. Тобто, на перший погляд, це свідчить, що всі установи є суб'єктами державного сектору і мають застосовувати ці положення. Але в НП(С)БОДС 101 «Пдання фінансової звітності» чітко визначено, що законодавець має під поняття «суб’єкт державного сектору». Суб'єкти державного сектору — суб'єкти бухгалтерського обліку в державному секторі, зокрема розпорядники бюджетних коштів, Казначейство та державні цільові фонди [8]. Тобто, це всі установи сектору загального державного управління. I як визначено в Класифікації секторів економіки, сектор загального державного управління (ЗДУ) об'єднує юридичних осіб, для яких основною діяльністю є виконання функцій законодавчої, виконавчої або судової влади відносно інших інституційних одиниць у межах певної території. Вони мають повноваження збирати податки та інші обов'язкові платежі, а також витрачати їх відповідно до урядової політики. Сектор загального державного управління включає: - усі одиниці центральних, регіональних, місцевих органів управління; - усі неринкові некомерційні організації (НКО), які контролюються і в 
основному фінансуються органами управління. Розподіл сектору ЗДУ за підсекторами здійснюється так: - центральні органи державного управління; - регіональні та місцеві органи управління; - фонди соціального страхування [9].

Висновки і перспективи подальших досліджень. Відповідно до проведеного аналізу структури державного сектору та іï взаємозв'язку з бухгалтерським обліком, можна 3 впевненістю сказати, що державний сектор є багатовекторним. Зокрема цьому підтвердження $\epsilon$ те, що установи державного сектору можна поділити на різні групи саме за веденням бухгалтерського обліку та його організацією. Тобто в структурі установ державного сектору застосовуються субрахунки бухгалтерського обліку чотирьох різних Планів рахунків.

Отже, дослідження структури державного сектору у розрізі законодавчо визначених та наукового обгрунтованих підходів дозволило сформувати основні принципи архітектоніки державного сектору. Зокрема визначено та розмежовано наукові поняття «державна установа» та «державне підприємство», як основні суб' єкти державного сектору, які забезпечують ефективну та безперебійну діяльність загалом держави. Оскільки на суб'єктів державного сектору покладаються основні функції органів законодавчої, виконавчої та судової влади, органів місцевого самоврядування, державних цільових фондів, державних фінансових та нефінансових установ. Саме від функціонального, відомчого та бюджетного призначення установи залежить як загальна архітектоніка державного сектору, так і їх взаємозв'язок з бухгалтерським обліком. Для ефективного управління установами державного сектору потрібно мати достовірну, актуальну та відповідним чином згруповану інформацію про активи, зобов'язання, власний капітал та фінансовий результат виконання кошторису. Але для детального розуміння та визначення основних принципів управління державними фінансами на основі даних бухгалтерського обліку доцільно детально досліджувати становлення та розвиток управління державними фінансами та провести детальний аналіз основних підходів до інтерпретації та класифікації активів державних установ.

\section{Джерела та література}

1. Бюджетний кодекс України №2456-VI від 01.01.2021. URL: https://zakon.rada.gov.ua/laws/show/245617\#Техt (дата звернення: 14.04.2021)

2. Дрозд І.К. Бухгалтерський облік та внутрішній державний аудит за міжнародними стандартами : у 3 ч. / за заг. ред. М.В. Кужельного. К. : УАСБА, 2009. Ч. ІІ : Міжнародні стандарти внутрішнього аудиту державного сектору К., 2009. 312 с

3. Ловінська Л. Г. Бухгалтерський облік та внутрішній аудит в державному секторі : у 3 ч. / за заг. ред. М.В. Кужельного. К. :УАСБА, 2009. Ч.1 : Фінансовий облік у державному секторі:міжнародний підхід / Л.Г. Ловінська, С.В. Свірко, Т.І. Єфименко, О.О. Каниуров. К., 2009. 479 с

4. Лукьянчикова Н.П. Экономическая теория государства: учебное пособие. Иркутская государственная экономическая академия. Иркутск: ИГЭА, 2001.78 с.

5. Майстер А. В. Теоретичні підходи до визначення сутності державного сектору економіки та його оптимального розміру. Ефективна економіка. 2014. № 7. Режим доступу: http://nbuv.gov.ua/UJRN/efek_2014_7_29.

6. Макогон I. Державний сектор як об'єкт макроекономічного регулювання. Вісник Київського національного торговельно-економічного університету. 2015. № 3(1). С. 21-34. Режим доступу: http://nbuv.gov.ua/UJRN/Vknteu_2015_3(1)__3.

7. Мочерний С. В. Сектор державний. Економічна енциклопедія: у трьох томах. Т.3 Ред.кол.: С.В. Мочерний (відп.ред.) та ін. К.:Видавничий центр «Академія», 2002. 864 с.

8. Національне положення (стандарт) бухгалтерського обліку в державному секторі 101 «Подання фінансової звітності»: Наказ Міністерства фінансів України від 24.12.2010 № 1629. Дата оновлення 01.01.2015. URL: https://zakon.rada.gov.ua/laws/show/z0095-11\#Text (дата звернення 05.06.2021)

9. Про затвердження Класифікації інституційних секторів економіки України [Електронний ресурс]: наказ Державної служби статистики України від 03.12.2014 p. № 378. - Режим доступа: https://zakon.rada.gov.ua/rada/show/v0378832-14\#Text 
10.Про затвердження Плану рахунків бухгалтерського обліку активів, капіталу, зобов'язань і господарських операцій підприємств і організацій: затв. наказом Міністерства фінансів України від 09.12 .2011 p. № 1591. Дата оновлення 10.01.2012. URL: https://zakon.rada.gov.ua/laws/show/z1557-11\#Text

11.Про затвердження Плану рахунків бухгалтерського обліку банків України: затв. Постановою Правління Національного банку України від 11.09. 2017 р. № 89. Дата оновлення 05.10.2020. URL: https://zakon.rada.gov.ua/laws/show/v0089500-17\#n26

12. Про затвердження Плану рахунків бухгалтерського обліку в державному секторі: затв. наказом Міністерства фінансів України від 31.12. 2013 р. № 1203. Дата оновлення 21.01.2020. URL: https://zakon.rada.gov.ua (дата звернення 12.11.2020).

13. Про затвердження Стратегії модернізації системи бухгалтерського обліку в державному секторі на 2007-2015 роки: Постанова Кабінету Міністрів України від 16.01.2007 р. № 34 [Електронний ресурс]. - Режим доступу: https://zakon.rada.gov.ua/laws/show/34-2007-\%D0\%BF\#Text

14. Руководство по статистике государставенных финансов 2001 года / Стат. управление. - Режим доступу : https://www.imf.org/external/pubs/ft/gfs/manual/rus/index.htm

15. Свірко С. В. Суб'єкти та об'єкти бухгалтерського обліку в державному секторі України в контексті чинного вітчизняного законодавства. Незалежний аудитор : наук.-практ. вид., 2012. т.№ 2. С.36-42

16. Система национальных счетов 2008 года (СНС-2008). — Режим доступу : https://unstats.un.org/unsd/nationalaccount/docs/SNA2008 Russian.pdf.

17. Ходов Л. Г. Основы государственной экономической политики: Учебник. М.: БЕК, 1997. 332 с.

\section{References}

1. Bjudzhetnyj kodeks Ukrajiny vid 01.01.2021 №456-VI. [Budget Code of Ukraine from 01.01.2021 №2456VI] URL: https://zakon.rada.gov.ua/laws/show/2456-17\#Text (data zvernennja: 14.04.2021) [in Ukraine].

2. Drozd I.K. (2009) Bukhghaltersjkyj oblik ta vnutrishnij derzhavnyj audyt za mizhnarodnymy standartamy [Accounting and internal state audit according to international standards] : u 3 ch. / za zagh. red. M.V. Kuzheljnogho. K. : UASBA, 2009. Ch. II : Mizhnarodni standarty vnutrishnjogho audytu derzhavnogho sektoru / K.Drozd, O.O. Chechulina. K., 2009. p.312 . [in Ukraine].

3. Lovinsjka L.Gh. (2009) Bukhghaltersjkyj oblik ta vnutrishnij audyt v derzhavnomu sektori [Accounting and internal state audit according to international standards]: u 3 ch. / za zagh. red. M.V. Kuzheljnogho. - K. :UASBA, 2009. Ch.1 : Finansovyj oblik u derzhavnomu sektori:mizhnarodnyj pidkhid / L.Gh. Lovinsjka, S.V. Svirko, T.I. Jefymenko, O.O. Kancurov. K., 2009. p. 479. [in Ukraine].

4. Lukjjanchykova N.P. (2001) Эkonomycheskaja teoryja ghosudarstva: uchebnoe posobye/ Yrkutskaja ghosudarstvennaja эkonomycheskaja akademyja. Yrkutsk: YGhЭA, 2001. p.78. [in Russian].

5. Majster A. V. (2014) Teoretychni pidkhody do vyznachennja sutnosti derzhavnogho sektoru ekonomiky ta jogho optymaljnogho rozmiru [Theoretical approaches to determining the essence of the public sector of the economy and its optimal size]. Efektyvna ekonomika. 2014. \# 7. Rezhym dostupu: http://nbuv.gov.ua/UJRN/efek_2014_7_29. [in Ukraine].

6. Makoghon I. (2015) Derzhavnyj sektor jak ob'jekt makroekonomichnogho reghuljuvannja [The public sector as an object of macroeconomic regulation]. Visnyk Kyjivsjkogho nacionaljnogho torghoveljno-ekonomichnogho universytetu. 2015. \# 3(1). p. 21-34. Rezhym dostupu: http://nbuv.gov.ua/UJRN/Vknteu_2015_3(1)_3. [in Ukraine].

7. Mochernyj S. V. (2002) Sektor derzhavnyj [Public sector] Ekonomichna encyklopedija: u trjokh tomakh. T.3/ K.:Vydavnychyj centr «Akademija», 2002. p. 864. [in Ukraine].

8. Nakaz Ministerstva finansiv Ukrajiny Pro Nacionaljne polozhennja (standart) bukhghaltersjkogho obliku v derzhavnomu sektori 101 «Podannja finansovoji zvitnosti» vid 24.12.2010 № 1629 [Order of the Ministry of Finance of Ukraine On the National Regulation (Standard) of Accounting in the Public Sector 101 "Submission of Financial Statements" from 24.12.2010 № 1629] URL: https://zakon.rada.gov.ua/laws/show/z0095-11\#Text (data zvernennja 05.06.2021) [in Ukraine].

9. Nakaz Derzhavnoji sluzhby statystyky Ukrajiny Pro zatverdzhennja Klasyfikaciji instytucijnykh sektoriv ekonomiky Ukrajiny vid 03.12.2014 r. №378. [Order of the State Statistics Service of Ukraine On approval of the Classification of Institutional Sectors of the Economy of Ukraine from 03.12.2014] [Elektronnyj resurs]:- Rezhym dostupa: https://zakon.rada.gov.ua/rada/show/v0378832-14\#Text. [in Ukraine].

10. Nakaz Ministerstva finansiv Ukrajiny Pro zatverdzhennja Planu rakhunkiv bukhghaltersjkogho obliku aktyviv, kapitalu, zobov'jazanj i ghospodarsjkykh operacij pidpryjemstv i orghanizacij vid 09.12. 2011 r. № 1591. [Order of the Ministry of Finance of Ukraine On approval of the Chart of Accounts for accounting of assets, capital, liabilities and 
business operations of enterprises and organizations from 09.12.2011 № 1591] Data onovlennja 10.01.2012. URL: https://zakon.rada.gov.ua/laws/show/z1557-11\#Text [in Ukraine].

11. Postanova Pravlinnja Nacionaljnogho banku Ukrajiny Pro zatverdzhennja Planu rakhunkiv bukhghaltersjkogho obliku bankiv Ukrajiny vid 11.09. 2017 №89. [ Resolution of the Board of the National Bank of Ukraine On approval of the Chart of Accounts of banks of Ukraine from 11.09. 2017 № 89] Data onovlennja 05.10.2020. URL: https://zakon.rada.gov.ua/laws/show/v0089500-17\#n26. [in Ukraine].

12. Nakaz Ministerstva finansiv Ukrajiny Pro zatverdzhennja Planu rakhunkiv bukhghaltersjkogho obliku v derzhavnomu sektori vid 31.12. 2013 r. № 1203 [Order of the Ministry of Finance of Ukraine On approval of the Chart of Accounts in the public sector from 31.12. 2013 № 1203]. Data onovlennja 21.01.2020. URL: https://zakon.rada.gov.ua (data zvernennja 12.11.2020). [in Ukraine].

13. Postanova Kabinetu Ministriv Ukrajiny Pro zatverdzhennja Strateghiji modernizaciji systemy bukhghaltersjkogho obliku v derzhavnomu sektori na 2007-2015 roky vid 16.01.2007 №34 [ Resolution of the Cabinet of Ministers of Ukraine On approval of the Strategy for modernization of the accounting system in the public sector for 2007-2015 from 16.01.2007 № 34][Elektronnyj resurs]. - Rezhym dostupu: https://zakon.rada.gov.ua/laws/show/342007-\%D0\%BF\#Text[in Ukraine].

14. Rukovodstvo po statystyke ghosudarstavennukh fynansov 2001 ghoda [2001 Guide to Public Finance Statistics] / Stat. upravlenye. Rezhym dostupu : https://www.imf.org/external/pubs/ft/gfs/manual/rus/index.htm[in Russian].

15. Svirko S. V. (2012) Sub'jekty ta ob'jekty bukhghaltersjkogho obliku v derzhavnomu sektori Ukrajiny v konteksti chynnogho vitchyznjanogho zakonodavstva [Subjects and objects of accounting in the public sector of Ukraine in the context of current domestic legislation ]. Nezalezhnyj audytor : nauk.-prakt. vyd., 2012. t.\# 2.-p.36-42 [in Ukraine].

16. Systema nacyonaljnыkh schetov 2008 ghoda (SNS-2008). [System of National Accounts 2008 (2008 SNA)] Rezhym dostupu : https://unstats.un.org/unsd/nationalaccount/docs/SNA2008 Russian.pdf. [in Russian].

17. Khodov L.Gh. Osnovы ghosudarstvennoj эkonomycheskoj polytyky [Fundamentals of State Economic Policy]: Uchebnyk.M.: BEK, 1997.p. 332. [in Russian].

Стаття надійшла до редакції 18.11.2021 р. 